\title{
PENIPUAN PERNIKAHAN PERSPEKTIF HUKUM ISLAM (Studi Kasus Putusan Nomor 0375/Pdt.G/2017/PA Kdi )
}

\author{
Anistantia Putri Maulana \\ Pengurus Ikatan Alumni Pondok Modern Darussalam Gontor Putri \\ Email: tantiaduppont@gmail.com
}

\begin{abstract}
Abstrak
Penelitian ini berkenaan dengan Penipuan Pernikahan Perspektif Hukum Islam Studi Kasus Putusan Nomor 0357/Pdt.G/2017/PA Kdi. Masalah yang dikemukan dalam penelitian ini meliputi pertimbangan hakim dalam memutuskan kasus penipuan pernikahan; Bentuk dan dampak penipuan pernikahan; serta perspektif hukum Islam pada penipuan pernikahan. Penelitian ini menggunakan penelitian kualitatif dengan obyek yaitu, Pengadilan Agama Kendari, dengan melakukan teknik pengumpulan data dengan bentuk wawancara, observasi, dan dokumentasi. Hasil penelitian ini mengungkapkan bahwa hakim mengabulkan gugatan penggugat yang telah di tipu dengan menggunakan alat bukti yang kuat yaitu saksi dan bukti administrasi. Bentukbentuk penipuan yang terjadi dalam lingkup Pengadilan Agama Kendari yaitu pemalsuan identitas diri suami atau istri. Dampak yang terjadi terhadap korban penipuan pernikahan yaitu psikis, fisik serta kerugian materi. Penipuan pernikahan yang terjadi agar dapat diberi sanksi yang dapat membuat efek jerah terhadap pelaku-pelaku juga turut serta dalam melakukan penipuan pernikahan.
\end{abstract}

Kata kunci: Pernikahan, Penipuan, Hukum Islam

\begin{abstract}
This research concerning Marriage Fraud Perspective of Islamic Law Case Study of Decision Number 0357 / Pdt.G / 2017 / PA Kdi. The problems raised in this study include consideration of judges in deciding cases of marriage fraud; The form and impact of marriage fraud; as well as Islamic legal perspectives on marriage fraud. This study uses qualitative research with objects namely, Kendari Religious Court, by conducting data collection techniques in the form of interviews, observation, and documentation. The results of this study revealed that the judge granted the plaintiff's claim which had been deceived by using strong evidence, namely the witness and administrative evidence. Forms of fraud that occur within the scope of the Kendari Religious Court are the falsification of the identity of the husband or wife. The impact on the victims of marriage fraud is psychological, physical and material losses. Marriage fraud that occurs in order to be sanctioned that can make a reddish effect on the perpetrators also participates in committing marriage fraud.
\end{abstract}

Key words: Fraud, Marriage, Islamic Law 


\section{Pendahuluan}

Manusia secara alami mempunyai daya tarik antara satu dengan yang lainnya untuk membina suatu hubungan. Realisasi manusia dalam membina hubungan tersebut tentunya diperlukan suatu ikatan, baik secara lahir maupun batin yang disebut dengan pernikahan. Pernikahan merupakan sunatullah yang umum dan berlaku bagi manusia. Allah swt., menjadikan manusia dengan fitrahnya yang ingin hidup berpasangpasangan, berkasih sayang, bahagia dan dapat memenuhi tuntutan syahwatnya dengan cara yang halal. Fitrah tersebut dapat dilaksanakan melalui ikatan pernikahan yang sah. Sebagaimana firman Allah swt., dalam QS.ar-Rum /30 : 21.

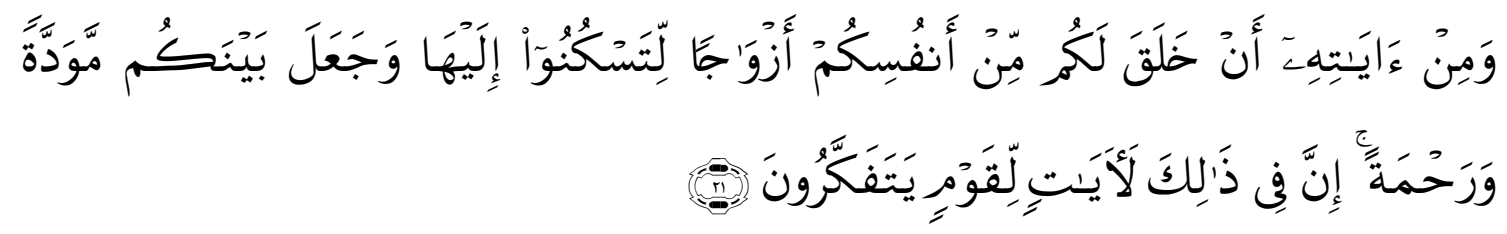

Terjemahnya:

"Dan di antara tanda-tanda kekuasaan-Nya ialah Dia menciptakan untukmu isteri-isteri dari jenismu sendiri, supaya kamu cenderung dan merasa tenteram kepadanya,dan dijadikan-Nya diantaramu rasa kasih dan sayang Sesungguhnya pada yang demikian itu benar-benar terdapat tanda-tanda bagi kaum yang berfikir."1 ( QS.ar-Rum /30 :21)

Agama Islam telah memberikan wadah penyaluran naluriah manusia untuk hidup berpasangan melalui jalur pernikahan. Pernikahan dapat menjadikan hidup manusia sebagai makhluk berpasangan terhormat. Oleh sebab itu, sangat relevan apabila Islam mengatur masalah perkawinan dengan teliti dan terperinci, untuk membawa umat manusia hidup berkehormatan, sesuai kedudukannya yang amat mulia di tengah-tengah makhluk Allah yang lain. ${ }^{2}$

Istilah perkawinan berdasarkan Undang-undang No. 1 Tahun 1974 tentang Perkawinan yaitu, ikatan lahir batin antara seorang laki-laki dengan seorang perempuan sebagai suami istri, dengan tujuan membentuk keluarga (rumah tangga) yang bahagia dan kekal berdasarkan Ketuhanan Yang Maha Esa. ${ }^{3}$ Pada Pasal 2 Kompilasi Hukum Islam Pernikahan yaitu Akad yang sangat kuat atau mitśaqan ghaliżan untuk mentaati perintah Allah dan melaksanakannya merupakan ibadah. Pernikahan adalah "ikatan

\footnotetext{
${ }^{1}$ Kementrian Agama RI, al-Qur'an dan Terjemahnya, Jilid II (Jakarta: Direktorat Jendral Bimbingan Masyarakat Islam Direktorat Urusan Agama Islam dan Pembinaan Syariah, 2012), h.406.

${ }^{2}$ Ahmad Azhar Basyir, Hukum Perkawinan Islam (Cet.ix ; Yogyakarta : UII Press, 1999), h. 1

${ }^{3}$ Undang-undang No. 1 Tahun 1974 tentang Perkawinan (Jakarta: Buana Ilmu Populer, 2017), h. 3.
} 
lahir batin" bahwa pernikahan tidak cukup dengan adanya ikatan lahir saja atau batin saja. Akan tetapi hal ini harus ada keduanya, sehingga akan terjalin ikatan lahir dan batin yang merupakan pondasi yang kuat dalam membentuk dan membina keluarga yang bahagia dan kekal. ${ }^{4}$ Pernikahan tidak hanya mengandung unsur hubungan manusia dengan manusia sebagai hubungan keperdataan tetapi, disisi lain perkawinan juga memuat unsur sakralitas yaitu hubungan manusia dengan Allah. ${ }^{5}$

Tujuan pernikahan menurut UU Perkawinan adalah membentuk keluarga (rumah tangga) yang bahagia dan kekal berdasarkan Ketuhanan Yang Maha Esa. Pernikahan yang bertujuan untuk membentuk keluarga yang bahagia dan kekal, dapat diartikan bahwa pernikahan itu haruslah berlangsung seumur hidup dan tidak boleh diputuskan begitu saja. Putusnya hubungan pernikahan dapat terjadi karena 3 (tiga) hal, yaitu (1) Kematian, (2) Perceraian, (3) Atas putusan pengadilan. ${ }^{6}$

Kompilasi Hukum Islam telah mengatur pada Pasal 72 istri ataupun suami dapat mengajukan pembatalan perkawinan apabila pada waktu berlangsungnya perkawinan terjadi penipuan atau salah sangka. Permohonan pembatalan perkawinan diajukan kepada Pengadilan dalam daerah hukum dimana perkawinan tersebut dilangsungkan atau ditempat tinggal suami-istri (Pasal 25 UU No.1 tahun 1974). Fenomena yang terjadi di Pengadilan Agama Kendari, penipuan atau salah sangka yang terjadi pada pernikahan menjadi alasan cerai talak maupun cerai gugat pada kasus perceraian yang ada. Alasan-alasan perceraian tidak hanya pada penelantaran, KDRT (kekerasan dalam rumah tangga), pertengkaran, dan ketidakcocokan ataupun bosan. Pada saat ini, alasan perceraian sudah masuk ke dalam ranah salah sangka ataupun adanya penipuan dalam pernikahan. Para Penggugat dan Pemohon mengajukan kepada pengadilan agar diputuskan pernikahannya dengan beragam alasan salah satunya adanya penipuan dalam pernikahan.

Penipuan pernikahan sering terjadi dikalangan masyakat Indonesia, bahkan sangat meresahkan karena banyak masyarakat menjadi korbannya. Hukum Islam di Indonesia menyelesaikan permasalahan ini, jika adanya aduan dari yang bersangkutan

\footnotetext{
${ }^{4}$ Abdurrahman, Kompilasi Hukum Islam di Indonesia (Cet. II: Jakarta: CV. AkademikaPressindo, 1995), h. 114.

${ }^{5}$ Wasman dan Wardah Nuroniyah, Hukum Perkawinan Islam di Indonesia Pebandingan Fiqih dan Hukum Positif(Yogyakarta: Teras, 2011), h. 29.

${ }^{6}$ Amir Syarifuddin, Hukum Perkawinan di Indonesia (Jakarta : Prenata Media, 2007), h.9.
} 
dengan cara perceraian ataupun pembatalan pernikahan melalui pengadilan agama. Pengadilan Agama tidak memiliki payung hukum untuk memberi sangsi badan terhadap pelaku-pelaku penipuan pernikahan agar terjadi efek jerah.

Pada pengadilan Agama Kendari beberapa tahun belakangan ini, pada observasi awal, telah menangani \pm 10 kasus penipuan pernikahan terhadap diri istri ataupun suami, ${ }^{7}$ yaitu dengan mengaku perawan tetapi, telah berbadan dua dan mengaku perjaka atau duda cerai mati ataupun hidup, lalu menikah untuk yang kedua ataupun seterusnya. Penipuan atau salah sangka seperti ini menjadi salah satu alasan dalam memutuskan pernikahan yang diajukan di Pengadilan Agama Kendari. Salah satu kasus tersebut yaitu dengan Nomor Putusan : 0357/Pdt.G/2017/PA Kdi, Penggugat pada kasus ini menggugat suaminya dengan perceraian karena, merasa tertipu dengan status suaminya yang mengaku jejaka tetapi, telah beristri sebelumnya, juga sering melakukan kdrt terhadap Penggugat.

Pembatalan dan perceraian penikahan termasuk kompetensi absolute Pengadilan dalam Lingkungan Peradilan Agama. Pengadilan Agama bertugas dan berwenang, memeriksa, memutus, dan menyelesaikan perkara-perkara ditingkat pertama antara orang-orang yang beragama islam dalam bidang perkawinan, ${ }^{8}$ kewarisan, wasiat, hibah, wakaf dan sedekah yang dilakukan menurut hukum Islam.

\section{Metode Penelitian}

Penelitian ini dilakukan di Pengadilan Agama Kendari. Perolehan data primer pada penelitian ini, dilakukan melalui wawancara dengan pihak pengadilan Agama Kendari yaitu hakim, penggugat dan tergugat. Wawancara dilakukan bebas terpimpin, yaitu wawancara dengan mempersiapkan daftar pertanyaan terlebih dahulu yang dipakai sebagai pedoman, tetapi dimungkinkan variasi pertanyaan yang disesuaikan dengan situasi pada saat wawancara dilakukan. Perolehan data sekundernya melalui telaah mendalam terhadap literatur atau referensi kepustakaan, serta dokumen lainnya sebagai data pendukung untuk melengkapi data primer yang relevan dengan judul penelitian seperti, yurisprudensi dan Undang-Undang yang berkaitan dengan penelitian ini.

\footnotetext{
${ }^{7}$ S, Bagian Perkara di Pengadilan Kendari, Tanggal 16 Oktober 2017.

${ }^{8}$ Abdul Manan, Penerapan Hukum Acara Perdatadi Lingkungan Peradilan Agama (Jakarta : Kencana Perdata Media Grup 2006), h. 13
} 


\section{Pernikahan}

Pernikahan dalam literatur fiqh berbahasa Arab disebut dengan dua kata, yaitu nikah (نكاح) dan zawaj زواج. Kedua kata ini yang terpakai dalam kehidupan sehari-hari orang Arab dan banyak terdapat dalam al-Qur'an dan hadis Nabi. Kata $n a-k a-h a$ banyak terdapat dalam al-Qur'an dengan arti kawin", secara istilah yaitu ikatan lahir batin seorang pria dan wanita sebagai suami istri. Pada pernikahan ada syarat dan rukun yang harus di penuhi dalam pernikahan yaitu adanya calon mempelai, wali, saksi, serta ijabkabul. Penikahan di indonesia tidak hanya harus memenuhi unsur agama melainkan juga unsur bernegara dengan mencatatkan pernikahan, ini sebagaimana tertuai dalam Undang-Undang No.1 Tahun 1974 Pasal 2 juga dijelaskan bahwa :

(1) Perkawinan adalah sah, apabila dilakukan menurut hukum masing-masing agamanya dan kepercayaannya.

(2) Tiap-tiap perkawinan dicatat menurut peraturan perundang-undangan yang berlaku. ${ }^{10}$

Pernikahan mempunyai Asas-asas atau prinsip-prinsip menurut Undang-undang Nomor 1 Tahun 1974 adalah pembentukan keluarga bahagia dan kekal, pernikahan yang sah menurut masing-masing agamanya, pencatatan pernikahan, asas monogami terbuka, prinsip calon suami istri sudah masak jiwa raganya, batas umur pernikahan, perceraian dipersulit, kedudukan suami istri seimbang. ${ }^{11}$ Pernikahan bukan hanya mempersatukan dua pasangan manusia, yakni laki-laki dan perempuan, melainkan mengikatkan tali perjajnjian yang suci atas nama Allah, bahwa kedua mempelai berniat membangun rumah tangga yang sakinah mawaddah dan rahmah. Untuk mewujudkannya tidak hanya bersandar pada ajaran-ajaran Allah dalam al-Qur'an dan as-Sunnah yang bersifat global, tetapi pernikahan berkaitan pula dengan hukum suatu negara. Pernikahan dinyatakan sah menurut hukum Allah dan hukum agama apabila telah memenuhi rukun serta syaratnya.

${ }^{9}$ Ahmad Azhar Basyir, Hukum Perkawinan Islam (Yogyakarta: UII, 2000), h. 14.

${ }^{10}$ Undang-undang No. 1 Tahun 1974 tentang Perkawinan (Jakarta: Buana Ilmu Populer, 2017), h. 2 .

\footnotetext{
${ }^{11}$ Ahmad Azhar Basyir, Hukum Perkawinan Islam (Yogyakarta: UII, 2000), h. 23.
} 


\section{Penipuan pernikahan}

Penipuan pernikahan telah lama terjadi dengan keadaan yang berbeda pada kehidupan manusia, terutama dengan memalsukan keadaan dirinya secara fisik ataupun status sosial demi kepentingan pribadi pelaku. Peraturan penipuan pernikahan di atur pada hukum agama Islam dan hukum negara.

Pertama, Pernikahan yang sah, dalam hukum Islam harus memenuhi syaratsyarat dan rukun pernikahan, perlu diperhatikan juga ketentuan-ketentuan yang ada dalam hukum pernikahan Islam. Apabila dikemudian hari diketemukan penyimpangan terhadap syarat sahnya pernikahan, maka pernikahan tersebut dapat dibatalkan. Batalnya pernikahan menjadikan ikatan pernikahan yang telah ada menjadi putus. Pernikahan ini dapat diartikan tidak pernah ada, dan suami istri yang pernikahannya dibatalkan dianggap tidak pernah nikah sebagai suami istri. Pembatalan pernikahan dalam hukum Islam disebut fasakh yang artinya merusak atau membatalkan. Bila ada kata-kata fasakh ba'i berarti pembatalan akad jual beli karena adanya suatu sebab/illat/cela. Sedangkan fasakh nikah adalah pembatalan perkawinan oleh istri karena antara suami istri terdapat cacat atau penyakit yang tidak dapat disembuhkan, atau si suami tidak dapat memberi belanja/nafkah, menganiaya, murtad dan sebagainya. ${ }^{12}$ Maksud dengan fasakh nikah adalah memutuskan atau membatalkan ikatan hubungan antara suami istri.Jadi fasakh sebagai salah satu sebab putusnya pernikahan ialah merusakkan atau membatalkan hubungan pernikahan yang telah berlangsung. Apabila terjadi pembatalan perkawinan, baik dalam bentuk pelanggran terhadap hukum perkawinan, atau terdapatnya halangan yang tidak memungkinkan dilanjutkannya pernikahan, maka terjadilah akibat hukum berupa tidak diperbolehkannya suami rujuk kepada mantan istrinya selama istri itu menjalani masa iddah. Akan tetapi apabila keduanya berkeinginan untuk melanjutkan pernikahannya, meraka harus melakukan akad nikah baru, pembatalan perkawinan tersebut tidak mengurangi bilangan thaläq. $^{13}$

Kedua, Penipuan pernikahan pada Kompilasi Hukum Islam di muat pada Pasal 72 yaitu "Seorang suami atau istri dapat mengajukan permohonan pembatalan

12 Amin Syarifuddin, Hukum Perkawinan Islam di Indonesia, Antara Figh Munakahat dan Undang-undang Perkawinan (Jakarta : Kencana, 2006), h.253.

${ }_{13}$ Amin Syarifuddin, Hukum Perkawinan Islam di Indonesia, Antara Fiqh Munakahat dan Undang-undang Perkawinan ..., h. 253. 
perkawinan apabila pada waktu berlangsungnya perkawinan terjadi penipuan atau salah sangka mengenai diri suami atau istri. Adapun Pasal 27 Undang-undang Perkawinan, ${ }^{14}$ sebagaimana Pasal 72 Kompilasi Hukum Islam mengatur hak-hak suami atau isteri untuk mengajukan pembatalan manakala perkawinan dilangsungkan dalam keadaan diancam, ditipu atau salah sangka. Undang-undang Nomor 1 Tahun 1974 tentang Perkawinan dan Peraturan Pemerintah Nomor 9 Tahun 1975 tentang batalnya perkawinan tidak secara tegas dinyatakan adanya lembaga nikahul fasid dalam Hukum Perkawinan di Indonesia. ${ }^{15}$ Pada Undang-Undang hanya terdapat pasal-pasal peraturan perundang-undangan tersebut memberikan kewenangan kepada Pengadilan Agama untuk membatalkan suatu pernikahan apabila pernikahan itu dianggap tidak sah atau apabila suatu pernikahan dianggap syarat-syarat pernikahan yang telah ditentukan atau apabila pernikahan yang sudah dilaksanakan itu diketahui ada cacat hukum sebagai akibat dari suatu kebohongan dan kekeliruan karena adanya paksaan.

Pernikahan pula dapat dibatalkan apabila seorang melakukan poligami tanpa izin pengadilan Agama, perempuan yang dinikahi kemudian diketahui masih menjadi istri pria lain secara sah, pernikahan yang melanggar batas umur sebagaimana yang ditentukan dalam Pasal 78 Undang-Undang Nomor 1 Tahun 1974 tentang Perkawinan, pernikahan yang dilangsungkan dimuka pegawai pencatat perkawinan yang tidak berwenang, wali nikah yang tidak sah atau pernikahan yang dilangsungkan tanpa dihadiri oleh dua orang saksi, pernikahan dilaksanakan dengan paksaan, pernikahan dilaksanakan dengan ancaman melanggar hukum, pernikahan dilaksanakan dengan penipuan penipuan disni mengaku jejaka padahal telah mempunyai sorang istri ketika pernikahan dilangsungkan, sedangkan ia melanggar karena poligami tanpa izin Pengadilan Agama. ${ }^{16}$

Hakekat dari kejahatan penipuan itu adalah untuk menguntungkan diri sendiri atau orang lain secara melawan hak, dengan mepergunakan upaya-upaya penipuan seperti yang disebutkan secara limitative di dalam Pasal 378 KUHP. Menurut M. Sudrajat Bassar, penipuan adalah suatu bentuk berkicau "sifat umum dari perbuatan

\footnotetext{
${ }^{14}$ Ahmad Rofiq, Hukum Islam Di Indonesia (Jakarta : Grafindo Persada, 1998), h.148.

15 Abdul Manan, Aneka Masalah Hukum Perdata Islam di Indonesia (Jakarta : Kencana Pranada Media ,2008), h.44

${ }^{16}$ Abdul Manan, Aneka Masalah Hukum Pedata di Indonesia ...,h.48.
} 
berkicau itu adalah bahwa orang dibuat keliru, dan oleh karena itu ia rela menyerahkan barang atau uangnya." 17

Menurut Yahya Harahap, secara teoritis Undang-undang Nomor 1 Tahun 1974 tentang Perkawinan bahwasanya perkawinan yang dianggap sendirinya yaitu batal menurut prinsip bahwa tidak ada suatu perkawinan yang dianggap sendirinya batal menurut hukum sampai ikut campur tangan pengadilan. Hal ini dapat diketahui dalam Pasal 37 Peraturan Pemerintah Nomor 9 Tahun 1975 tentang Pelaksanaan UndangUndang Nomor 1 Tahun 1974 tentang Perkawinan berkaitan dengan batalnya perkawinan. Pernyataan M. Yahya Harahap realistis karena suatu yang dilaksanakan melalui yuridis formal, maka untuk menghilangkan legalitas yuridis itu haruslah melalui putusan pengadilan agama agar mendapat putusan yang legal serta sesuai dengan hukum yang berlaku. ${ }^{18}$

Referensi hukum dalam memecahkan masalah keperdataan di Indonesia yaitu Undang-undang RI Nomor 1 Tahun 1974 tentang perkawinan yang merupakan peraturan perundang-undangan yang berlaku umum bagi seluruh warga negara Indonesia. Konteks Indonesia, perkembangan pemikiran hukum Islam menurut Mashun Fuad menggunakan teori adabtabilitas hukum Islam yaitu : (1) Penegakan kembali peran ijtihad; (2) Kontekstualisasi hukum Islam; (3) Kemaslahatan berbasis keadilan sebagai tujuan hukum Islam; (4) Liberalisasi hukum Islam ${ }^{19}$. Oleh karena itu, pada persoalan-persoalan pernikahan khususnya mengenai penipuan, dalam hukum Islam dan hukum nasional Indonesia diperlukan adanya ijtihad dengan mempertimbangkan dari segala aspek untuk melahirkan peraturan baru yang dapat dijadikan payung hukum. Teori ini dapat digunakan untuk menjabarkan dimensi wahyu yang normatif dalam menjawab perubahan sosial yang semakin berkembang. Hal ini umumnya menjadi masalah krusial di Indonesia, khususnya dalam kasus penipuan pernikahan yang terjadi terhadap masyarakat.

\footnotetext{
${ }^{17}$ Bassar Sudrajat, Tindak-tindak Pidana Tertentu dalam KUHP (Bandung : Remaja Karya, 1986), h. 81.

${ }^{18}$ M.Yahya Harahap, Hukum Perkawinan Nasional (Medan: Zahit Tranding, 2009), h.45.

${ }^{19}$ Mashun Fuad, Hukum Islam di Indonesia; dari nalar partisipator hingga emansipator (Cet, 1; Yogyakarta; lkis, 2005), h.282.
} 


\section{Pertimbangan Hakim dalam Memutuskan Perkara Penipuan Pernikahan.}

Perkara penipuan pernikahan di pengadilan Agama pada umumnya tidak nampak jelas layaknya perkara yang ada pada pengadilan seperti, warisan, wakaf, pengangkatan anak, itsbat nikah, perceraian dan sebagainya. Penipuan dalam pernikahan akan muncul kepermukaan dengan adanya aduan dari orang yang mengalaminya seperti istri/suami yang mengalami salah sangka atau tertipu terhadap pasangannya, dengan mengajukan permohonan ataupun gugatan. ${ }^{20}$ Salah satu dari kasus tersebut dengan nomor perkara Nomor : 0357/Pdt.G/2017/PA Kdi, yang mana dalam perkara ini penggugat meminta bercerai dengan termohon karena merasa tertipu dengan keadaan termohon yang mengaku lajang ternyata telah memliki istri terdahulu yang sah. Jadi penipuan dalam pernikahan adalah salah satu sebab dari putusnya ikatan pernikahan, dikarenakan belum ada peraturan yang mengatur lebih rinci tentang penipuan dalam pernikahan. ${ }^{21}$

Pertimbangan hakim dalam mengabulkan perkara ini dikarenakan, terjadinya penipuan status suami yang mengaku jejaka ternyata telah memiliki istri terdahulu, memicu pertengkaran terus menerus juga adanya kdrt, fakta hukum tersebut telah memenuhi norma hukum Islam yang terkandung dalam kitab Ghoyatul Muram Lissyaihil Majidi yang menjadi pendapat hakim sendiri sebagai berikut $:^{22}$

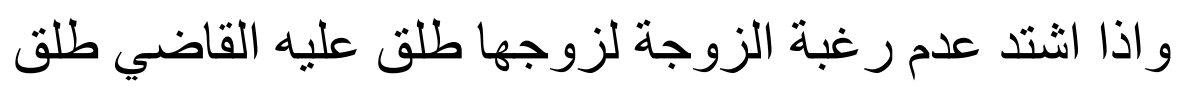

Terjemahannya:

"Dan apabila ketidak sukaan istri terhadap suami sudah sedemikian rupa, maka hakim boleh menjatuhkan talaknya suami itu dengan talak satu."

Maka hakim mengabulkan gugatan Penggugat dengan menggunakan bukti administrasi akta nikah, bahwa memang meraka adalah pasangan suami istri, lalu dua orang saksi yang mengetahui bahwa gugatan Penggugat benar adanya. Olehnya itu hakim Menjatuhkan talak satu ba'in sughra Tergugat ( $\mathrm{H}$ bin $\mathrm{A})$ terhadap Penggugat (SHN binti M). ${ }^{23}$

\footnotetext{
${ }^{20}$ Sutriana, Bagian Perkara Pengadilan Agama Kendari, Tanggal 26 Januari 2018.

${ }^{21}$ Rusdianto, Bagian Kepegawaian Pengadilan Agama Kendari, Tanggal 26 Januari 2018.

${ }^{22}$ Putusan Perkara Nomor : 0357/Pdt.G/2017/PA Kdi

${ }^{23}$ Putusan Perkara Nomor : 0357/Pdt.G/2017/PA Kdi
} 


\section{Bentuk dan dampak Penipuan Pernikahan}

Pada Pengadilan Agama kendari terjadi beberapa bentuk penipuan dalam pernikahan. Pemalsuan identitas pernikahan sering terjadi dan merugikan bagi para korbannya, hal ini sering dilakukan di dalam surat pernikahan mengenai pemalsuan identitas calon mempelai dalam mengisi surat-surat pernikahan sebelum kedua mempelai melakukan pernikahan.

Pertama, Penipuan identitas yang dimaksud adalah pemalsuan terhadap identitas pendidikan, pekerjaan, serta status sosial. Penipuan ini jika dilakukan oleh pria terkadang mengakui dirinya sebagai TNI ataupun aparat negara lainnya agar lawan jenis dapat terpikat olehnya, sedangkan perempuan terkadang mengakui dirinya berpendidikan tinggi dan mempunyai keterampilan serta sopan santun yang baik. ${ }^{24}$ Berdasarkan informan yang penulis wawancarai beliau mengatakan bahwa :

"Saya mengaku berpendidikan tinggi, pekerjaan saya bagus dan saya adalah aparat negara, pikir saya jika saya jujur hanya seorang pedagang pasti orang yang saya sasar tidak akan mau menikahi saya, saya punya istri terdahulu tapi orang yang saya sasar ini saya cinta kalau saya jujur pasti dia tidak mau dan lagi saya mampu membiayai semua". ${ }^{25}$

Ujian dalam faktor ekonomi bukan hanya ketika kekurangan materi, bahkan ketika kelebihan materi itu juga menjadi godaan untuk melakukan perbuatan tidak benar. Merasa diri mampu dan dapat bertanggung jawab di tempat yang salah dapat berakibat buruk bagi orang lain serta dapat merugikan.

Kedua, Penipuan status yang dimaksud adalah pemalsuan terhadap status lajang (perwan/perjaka), janda, atau duda serta agama yang di anut. Penipuan ini banyak dilakukan oleh orang-orang yang hendak melakukan poligami ataupun yang mengambil keutungan sepihak dengan jalur pernikahan. Penipuan ini dilakukan dengan cara mengakui dirinya duda cerai, cerai mati ataupun jejaka agar dapat menikah lagi, sedangkan untuk wanita mengakui dirinya gadis ternyata masih terikat pernikahan yang sah dengan penikahan sebelumnya ataupun untuk menutupi aib yang ada pada dirinya. Hal ini juga di benarkan oleh penggugat yang menggugat cerai suaminya karena tertipu dengan status suaminya yang mengaku jejaka ternyata suami orang lain informan mengatakan bahwa :

\footnotetext{
${ }^{24}$ M. Nasruddin, Wawancara, tgl 19 Januari, 2018.

${ }^{25} \mathrm{R}$, Tergugat, Tanggal 5 Februari 2018.
} 
"Saya menggugat cerai suami saya karena ternyata dia sudah punya istri terdahulu masih resmi mbak, pas kita menikah mengakunya bujang ktpnya bujang sama ada temannya bilang juga bujang keluarganya disini juga tidak memberi tahu, ternyata ketahuan dari pesta saudara kebetulansaya hadir ada yang bilang kalau suami saya sekarang ini sudah punya istri dan anak di kota lain, maka dari itu saya minta cerai karena saya merasa di tipu kecewa marah pokoknya saya sudah tidak bisa melanjutkan perkawinan ini." 26

Berdasarkan penjelasan dari informan-informan bahwa pemalsuan identitas terjadi dalam lingkup pernikahan memang benar adanya, ini dikarenakan adanya kerja sama antara oknum yang mengurus persiapan pernikahan dan pelaku dalam memanipulasi data seperti status jejaka serta tempat tinggal yang mengakibatkan terjadinya pemalsuan identitas.

Masalah penipuan pernikahan pada masyarakat kerap kali terjadi, hanya saja banyak yang tidak memperdulikan secara serius karena walaupun tertipu, tetap masih membutuhkan suami atau istri dalam rumah tangganya. Alasan mempertahankan pernikahan walaupun didalamnya banyak kepalsuan yaitu, malu apabila mengakhiri pernikahan merasa gagal, anak-anak yang masih kecil, atau secara ekonomi tergantung kepada si suami atau si istri. ${ }^{27}$ Penipuan pernikahan yang terjadi dalam pernikahan terselesaikan dengan jalan perceraian dan pembatalan pernikahan. Melalui proses pembatalan ataupun perceraian jelas akan mempunyai dampak bukan hanya dari hubungan tersebut tetapi, terhadap korban secara pribadi. Orang yang telah pernah kecewa dalam masalah pernikahan terkadang akan lama sembuhnya. Kekecewaan yang di hadapi serta rasa malu akan menimbulkan kurang percaya diri, serta terkadang menjadi trauma yang berkepanjangan disebabkan kebohongan yang terjadi dalam suatu hubungan. Ibu S selaku Penggugat serta korban kebohongan suaminya yang mengaku jejaka ternyata telah beristri terlebih dahulu dengan orang lain mengatakan bahwa :

"Akhirnya saya langsung bercerai, kecewa jelas yak mbak, saat saya tau bahwa suami saya itu adalah suami orang, saya sangat terpukul, saya tidak menyangka bahwa saya dibohongi, sempat keluar dari kerjaan saya, karena kurang fokus, sempat tergucang, yang selalu saya ingat kenapa bisa saya ambil suami orang, betapa berdosanya saya, akhirnya sampai saya keluar kota untuk menenangkan diri. ${ }^{28}$

\footnotetext{
${ }^{26}$ Ibu S I, Penggugat, Tanggal 23 Januari. 2018

${ }^{27}$ M. Nasruddin, Hakim Ketua Majelis Pengadilan Agama Kendari, Tanggal 19 Januari, 2018

${ }^{28}$ Ibu S, Penggugat, Tanggal 30 Januari 2018.
} 
Hal ini juga dialami oleh salah satu informan kami yaitu seorang suami yang tertipu oleh istrinya, yang telah mengandung anak orang lain saat mereka menikah. Ia mengatakan bahwa :

"Saya tidak tau kalau istri saya sedang hamil anak orang lain saat kami menikah, nanti pada saat saya periksa setelah menikah bahwa dia telah hamil 18 minggu, sedangkan pernikahan kami baru 14 minggu, saya kaget dan tidak bisa berkata-kata, kecewa jelas saya sangat kecewa, sampai-sampai malas kemana-mana mungkin itu depresi yang saya rasa, kerjaan berantakan akhirnya cuti karna tidak percaya apa yang saya alami." ${ }^{29}$

Penipuan dalam pernikahan bukan hanya menimbulkan dampak terhadap hubungan status seseorang semata tetapi dari segi harta benda serta terhadap korbannya secara pribadi. Dampak psikis dan fisik yaitu menarik diri ataupun merasa kecewa, trauma ini dapat terjadi terhadap pribadi orang-orang yang tertipu dalam masalah pernikahan. Korban bisa saja menjadi bahan cemohan orang-orang sekitarnya, serta menjadi sorotan terhadap istri pertama ataupun keluarganya.

\section{Perspektif Hukum Islam}

Hukum Islam (yang merupakan transliterasi dari Islamic Law ${ }^{30}$ dalam konsep barat) terdiri dari dua rangkaian kata yakni hukum dan Islam. Untuk mendapatkan pemahaman tentang pengertian hukum Islam perlu diketahui terlebih dahulu arti kata hukum. Kata hukum dalam bahasa Arab berakar dari kata fi'il ( كم ( ح-ك-م berarti menetapkan atau memutuskan. ${ }^{31}$ Islam dalam kamus bahasa Arab, berasal dari kata aslama yang artinya berserah diri, pasrah, tunduk, rekonsilisas (kepada kehendak Tuhan), kemudian menjadi salah satu nama agama setlah Yahudi, kristen dan agamaagama lain. ${ }^{32}$

${ }^{29} \mathrm{M}$ I, Pemohon, Tanggal 22 februari 2018.

${ }^{30}$ Dalam literaratur Barat, misalnya Joseph Schacht mendefenisikan Hukum Islam sebagai "the totality of Allah's commands that regulate the life of every Muslim in all its aspects" (keseluruhan kita Allah yang mengatur kehidupan setiap muslim dalam segala aspeknya). Defenisi ini cenderung menyamakan Hukum Islam dengan Syariat. Lihat Josepth Scahacht, An Introoduction to Islamic Law (Oxford :University Press, 1964), h.1.

${ }^{31}$ Ahmad Warson Munawwir, Kamus al-Munawwir Arab Indonesia, cet XIV (Surabaya Pustaka Progressif, 1997), h.286.

${ }^{32} \mathrm{Hans}$ Wehr, Mu'jam al-Lughah al-Arabiyyah al-Mu' ashirah, ed. J Milton Cowan, o (London Macdonald \&Evans Ltd, 1980) h.426 
Hukum Islam berarti seperangkat peraturan berdasarkan wahyu dan sunnah Rasul tentang tingkah laku manusia mukallaf yang diakui dan diyakini mengikat untuk semua yang beragama Islam. ${ }^{33}$

Perspektif hukum Islam terhadap Putusan hakim pada contoh putusan di atas, telah sesuai dengan hukum Islam yang mengedepankan kemaslahatan, yakni prinsip hukum Islam dalam skala prioritas harus memberikan kemaslahatan berupa kemanfaatan dan kegunaan, rumah tangga Penggugat dan Tergugat tidak lagi harmonis yang menyebabkan pisah rumah dikarenakan perselisihan yang terjadi antara Penggugat dan Tergugat secara terus menerus. Perselisihan ini terjadi dikarenakan Tergugat Mengaku jejaka saat menikahi Tergugat dan ternyata telah memiliki istri, serta ringan tangan terhadap Penggugat. Oleh karena itu, Penggugat mengajukan gugatan cerai, hal ini telah sesuai dengan hukum Islam dimana pernikahan yang didalamnya sudah tidak dapat mewujudkan tujuan pernikahan yaitu sakinah, mawaddah, warrahmah dapat dipisahkan. Hal ini sesuai dengan hadits Nabi saw., yaitu:

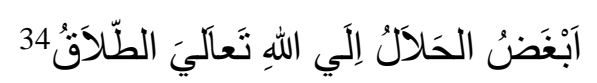

Artinya :

"Perkara halal yang paling Allah benci adalah Perceraian." (Imam AtTirmidzi 1863)

Hal ini juga di perkuat dengan firman Allah dalam QS. An-Nisa/4: 130 yaitu :

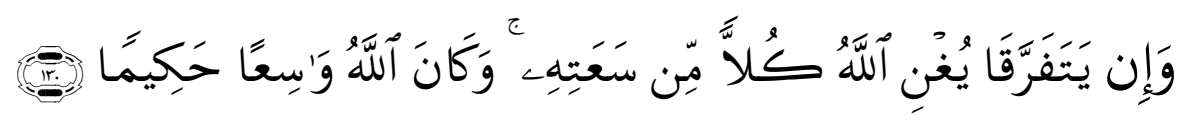

Terjemahannya :

"Jika keduanya bercerai, Maka Allah akan memberi kecukupan kepada masingmasingnya dari limpahan karunia-Nya. dan adalah Allah Maha Luas (karunia-Nya) lagi Maha Bijaksana." 35 (QS. An-Nisa /4: 130)

Penafsiran ayat ini menunjukkan bahwa kegagalan dalam pernikahan tidak boleh membuat manusia berputus asa, manusia harus senantiasa meminta petunjuk dan harapan kepada Allah swt. Usaha untuk membentuk kembali keluarga baru, baik dengan menikah lagi, atau kembali rujuk dengan pasangan sebelumnya jika pemaafan itu ada.

\footnotetext{
${ }^{33}$ Amir Syarifuddin, Pengertian dan Sumber Hukum Islam dalam Ismail Syah dkk. Filsafat Hukum Islam, Cet III (Jakarta : PT Bumi Aksara, 1999), h. 17-158.

${ }^{34}$ Imam At-Tirmidzi 1863

${ }^{35}$ Kementrian Agama RI, al-Qur'an dan Terjemahnya..,h.99.
} 
Penikahan yang sering terjadi perselisihan dan kebohongan didalamnya akan hanya melahirkan kemudharatan, maka lebih baik dipisahkan, dengan menghindari halhal yang tidak diinginkan terjadi dalam pernikahan ini. Kelebihan Islam dibandingkan agama-agama yang lain ada pada kemampuannya memberi solusi atas kenyataan yang terjadi dalam keluarga atau masyarakat. Solusi yang disampaikan oleh hukum Islam tidak kaku dan kering yang menyampaikan manusia kepada sebuah jalan buntu. Hukum Islam memberikan jalan keluar dengan baik fleksibel dan bertahap agar dapat dilaksanakan dengan baik bagi umat Islam.

Berdasarkan Pasal 70-76 KHI yang mengatur pembatalan pernikahan beberapa hakim mengatakan bahwa sangsi dari penipuan itu adalah pembatalan, dengan dibatalkan pernikahannya itulah yang menjadi sangsi sosial terhadap pelaku penipuan pernikahan. Pernikahan yang dibatalkan adalah pernikahan yang tidak pernah terjadi, di anggap tidak pernah ada. Menurut penulis sangsi ini belum cukup untuk menekan maraknya terjadi penipuan pernikahan, dikarenakan tidak semua orang merasa hina atau bersalah setelah melakukan kesalahan, terkadang lebih banyak orang yang tebal muka setelah melakukan kesalahan. Jadi apabila pembatalan dikatakan sangsi, ini hanya sangsi yang ringan, yang diharapkan adalah pelaku-pelaku penipuan pernikahan menurun dengan adanya sangsi yang membuat mereka berpikir ribuan kali untuk melakukan kejahatan tersebut.

Berkenaan dengan bentuk-bentuk penipuan pernikahan yang terjadi di Pengadilan Agama Kendari, yaitu bentuk penipuan identitas dan bentuk penipuan status. Bentuk-bentuk penipuan pernikahan ini tidak sesuai dengan hukum Islam, karena sifat dan karakteristik hukum Islam adalah kemanusian dan moralitas. Persoalan moral bukan hanya pada tatanan retorika melainkan lebih dipentingkan pada aplikasinya. Hal ini dapat dilihat misalnya kewajiban berlaku adil dan jujur meskipun terhadap orang yang dibenci, sebagaimana dijelaskan dalam QS. al-Maidah /5:8 sebagai berikut :

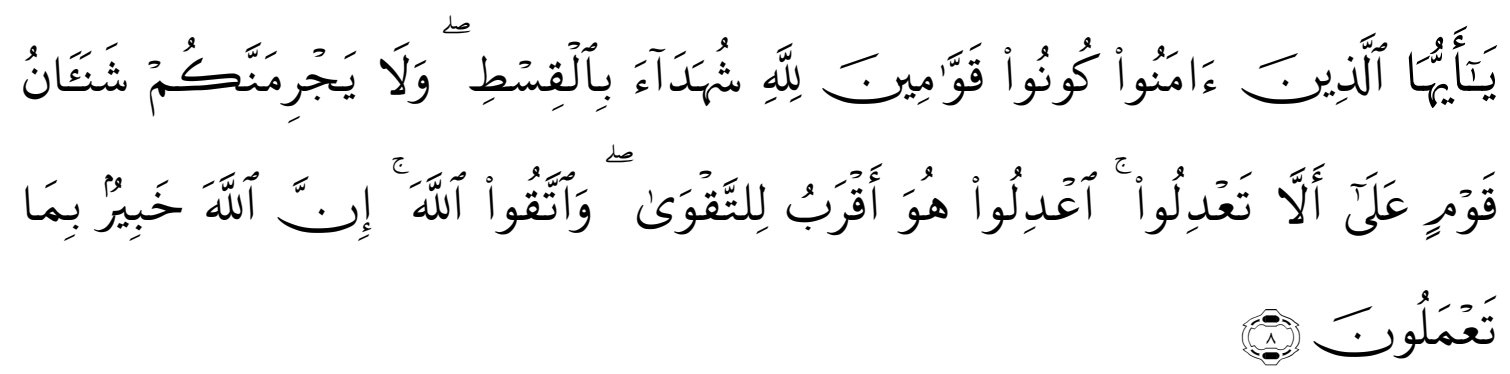


Terjemahnya :

"Hai orang-orang yang beriman hendaklah kamu jadi orang-orang yang selalu menegakkan (kebenaran ), karena Allah menjadi saksi dengan adil. Dan janganlah kamu sekali-kali kebencianmu terhadap suatu kaum mendorong kamu berlaku tidak adil. Berlaku adillah karena adil itu lebih dekat kepada takwa. Dan bertakwalah kepada Allah, sesungguhnya Allah maha mengetahui apa yang kamu kerjakan." ${ }^{36}$ (QS. al-Maidah /5:8)

Hukum Islam secara spesifik tidak mengatur tentang penipuan pernikahan, tetapi dapat diqiyaskan, dengan melihat betapa banyaknya perintah berlaku jujur dan larangan kebohongan, karena kobohongan akan membawa kemudharatan juga salah satu ciri-ciri orang munafik sebagaimana sabda Rasulullah saw., yaitu :

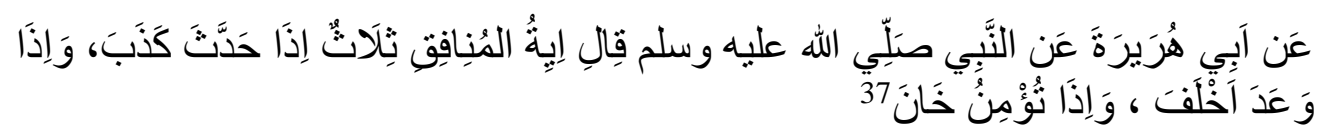

Artinya :

"Tanda-tanda orang munafik ada tiga : jika berbicara dia berdusta, jika berjanji dia mengingkari, dan jika diberi amanah dia berkhianat. (HR. Bukhari)

Berkenaan dengan adanya hadits ini, seperti diketahui bersama bahwa kemunafikan dapat menjadi tanda tidak adanya iman terhadap seseorang. Maka dalam Hukum Islam sifat munafik sangat dicela, dan agar menjauh darinya. Kemunafikan hanya akan membawa pada kemudharatan dan kesengsaraan, karena kebohongan dan pengingkaran yang dilakukan akan membawa kesukaran terhadap orang lain, hal itu sangat dilarang oleh ajaran Islam, karena tujuan Hukum Islam adalah kemaslahatan di dunia maupun di akhirat. Pelaku penipuan dalam pernikahan dapat dikatakan sebagai golongan orang munafik karena perkataannya adalah kebohongan, janji yang ia ucapkan ketika melakukan akad nikah diingkari, serta amanah sebuah keluarga yang diberikan dengan akad yang suci yaitu pernikahan, ia khianati dengan mengawali hubungan menggunakan kebohongan yang akan berdampak negatif. Maka perbuatan menipu tidak boleh dilakukan karena dapat mendatangkan kemudratan serta jauh dari kemaslahatan.

Dampak penipuan pernikahan yang terjadi lebih banyak membawa kemudharatan dari pada kemanfaatan. Ini tidak sesuai dengan hukum Islam yaitu kebahagiaan hidup manusia di dunia dan akhirat, dengan jalan mengambil segala yang bermanfaat dan mencegah serta menolak mudharat yang tidak berguna bagi hidup dan

\footnotetext{
${ }^{36}$ Kementrian Agama RI, al-Qur'an dan Terjemahnya, Jilid II (Jakarta: Direktorat Jendral Bimbingan Masyarakat Islam Direktorat Urusan Agama Islam dan Pembinaan Syariah, 2012), h.108.

${ }^{37}$ Shahih Bukhari no. 33.
} 
kehidupan, dimana hukum Islam bertujuan menjaga Agama, jiwa, akal, turunan dan harta, agar kemaslahatan itu tidak hanya untuk kehidupan di dunia melainkan pula untuk kehidupan di akhirat kelak. Pada dampak penipuan pernikahan ini, korban dirugikan dari segi psikis, fisik dan kekayaan serta malu terhadap lingkungan sekitar, yang dapat menjadikan korban dapat melakukan hal-hal buruk, jika tidak di dampingi keluarga yang dapat menenangkanya. Olehnya itu penipuan dalam pernikahan bukanlah hal yang dapat disepelekan dan didiamkan, karena membawa dampak buruk terhadap korban yang perlu di tindak lanjuti agar pelaku dapat di hukum atas perbuatannya. Allah swt., berfirman dalam QS an-Nahl / 16:126 yaitu :

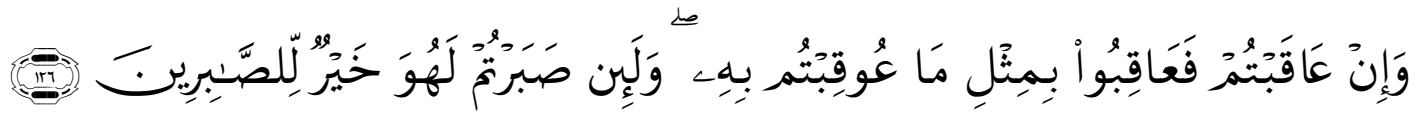

Terjemahnya :

"Dan jika kamu memberi balasan, maka balaslah dengan balasan yang sama dengan siksaan yang ditimpa kepadamu, akan tetapi jika mau bersabar, sesungguhnya itulah yang lebih baik bagi orang-orang yang sabar"38 (QS an-Nahl / 16:126)

Berdasarkan keterangan di atas, tampak bagaimana hukum Islam memperlihatkan masalah moralitas manusia dalam berinteraksi dengan sesamanya, dimana ada ketegasan yang perlu diterapkan menyangkut hak dan kewajiban sebagai manusia yang perlu dipenuhi. Hukum Islam selalu mengajarkan mediasi di setiap masalah yang dihadapi oleh umat Islam, akan tetapi tidak menjadikan hukum itu tidak terealisasikan. Memaafkan, mendamaikan antara korban dan pelaku adalah baik tetapi, hukuman dari pelaku kejahatan tetap dilaksakan. Pertanggung jawaban akibat perbuatannya terhadap orang lain yang merugikan, serta adanya efek jerah terhadap pelaku-pelaku kejahatan.

Pada kasus di atas Penggugat hanya memutuskan pernikahan yang terjadi, tetapi tidak menyikapi perbuatan tergugat yang merugikan Penggugat. Jika Penegakan hukum dilaksanakan maka segala kejahatan dalam rumah tangga bisa saja berkurang dengan adanya aturan hukum. Pengadilan Agama kendari hanya memutuskan pernikahan antara penggugat dan tergugat dengan cara perceraian, dengan melihat gugatan Penggugat yang meminta diceraikan. Kasus ini termaksud delik aduan absolut, hukum akan bertindak dengan adanya aduan dari korban yang bersangkutan. Beberapa dari korban

\footnotetext{
${ }^{38}$ Kementrian Agama RI, al-Qur'an dan Terjemahnya ..., h. 281.
} 
tidak melaporkan pelaku dikarenakan malu jika suaminya masuk penjara, mereka mempunyai anak-anak, terkadang hanya membuat kesepakatan terhadap pelaku dan keluarganya berupa ganti rugi ataupun tunjangan sampai waktu yang ditentukan. ${ }^{39}$

Mewujudkan kemaslahatan pada penipuan pernikahan akan lebih baik jika ada peraturan yang mengatur lebih detail tentang penipuan dalam pernikahan, agar dapat menekan pelaku-pelaku penipuan agar terjadi efek jerah. Peraturan dalam UndangUndang telah mengatur unsur-unsur penipuan serta sanksi hukuman tetapi belum secara tegas. Pada peraturan yang ada, kasus penipuan pernikahan dapat di jerat hukum yaitu si suami atau si istri yang melakukan pemalsuan identitas. Pada kenyataannya yang melakukan penipuan bukan saja calon mempelai melainkan keluarga serta aparat setempat yang turut serta membantu dalam pelaksanaan penipuan.

Oleh sebab itu alangkah lebih baik jika pemerintah membuat aturan-aturan yang dapat meminimalis kejahatan dalam rumah tangga yaitu penipuan pernikahan dengan membuat undang-undang terperinci terhadap kejahatan terhadap pernikahan dari bentuk-bentuk penipuan pernikahan yang ada agar dapat mencapai kemaslahatan yang diharapkan.

\section{Penutup}

Penipuan pernikahan biasanya dilakukan dalam bentuk pemalsuan identitas, misalnya mengaku perjaka padahal sudah pernah menikah. Penipuan bisa dilakukan suami, bisa pula oleh istri. Bentuk-bentuk penipuan pernikahan yang tejadi di Pengadilan agama ada 2 (dua) bentuk yaitu pertama, penipuan status, Kedua, Penipuan identitas. Dampak yang terjadi terhadap korban penipuan pernikahan yaitu trauma, malu (psikis) fisik serta kerugian materi. Perspektif hukum Islam terhadap putusan hakim masalah penipuan pernikahan adalah jika dilihat dengan menimbang dari segala sudut pandang agar mendapatkan kemaslahatan maka sudah sesuai dengan hukum Islam, namun jika dilihat bentuk-bentuk dan dampak penipuan pernikahan maka tidak sesuai dengan hukum Islam, karena sifat dan karakteristik hukum Islam adalah kemanusian dan moralitas, serta diwajibkannya berlaku adil dan jujur terhadap pasangan suami istri.

\footnotetext{
${ }^{39}$ Muhammadong, Hakim Anggota Pengadilan Agama Kendari, Tanggal 25 Januari, 2018.
} 


\section{DAFTAR PUSTAKA}

Abdurrahman. Kompilasi Hukum Islam di Indonesia Cet. II: Jakarta: CV. Akademika Pressindo, 1995.

Azhar Basyir Ahmad. Hukum Perkawinan Islam Cet.ix ; Yogyakarta : UII Press, 2000.

Fuad Mashun. Hukum Islam di Indonesia; dari nalar partisipator hingga emansipator Cet, 1; Yogyakarta; lkis, 2005

Harahap M.Yahya. Hukum Perkawinan Nasional Medan: Zahit Tranding, 2009.

Josepth Scahacht. An Introoduction to Islamic Law. Oxford :University Press, 1964.

Kementrian Agama RI. al-Qur'an dan Terjemahnya, Jilid II Jakarta: Direktorat Jendral Bimbingan Masyarakat Islam Direktorat Urusan Agama Islam dan Pembinaan Syariah, 2012.

Manan Abdul. Penerapan Hukum Acara Perdatadi Lingkungan Peradilan Agama Jakarta : Kencana Perdata Media Grup 2006.

Muhammadong. Hakim Anggota Pengadilan Agama Kendari, Tanggal 25 Januari, 2018.

M. Nasruddin. Hakim Ketua Majelis Pengadilan Agama Kendari, Tanggal 19 Januari, 2018

Rofiq Ahmad. Hukum Islam Di Indonesia Jakarta : Grafindo Persada, 1998.

Rusdianto. Bagian Kepegawaian Pengadilan Agama Kendari, Tanggal 26 Januari 2018

Syarifuddin,Amin. Hukum Perkawinan Islam di Indonesia, Antara Fiqh Munakahat dan Undang-undang Perkawinan (Jakarta : Kencana, 2006.

Syarifuddin Amir. Hukum Perkawinan di Indonesia Jakarta : Prenata Media, 2007.

Sutriana. Bagian Perkara Pengadilan Agama Kendari, Tanggal 26 Januari 2018.

Sudrajat Bassar. Tindak-tindak Pidana Tertentu dalam KUHP (Bandung : Remaja Karya, 1986)

Undang-undang No. 1 Tahun 1974 tentang Perkawinan Jakarta: Buana Ilmu Populer, 2017.

Wasman dan Wardah Nuroniyah. Hukum Perkawinan Islam di Indonesia Pebandingan Fiqih dan Hukum PositifYogyakarta: Teras, 2011.

Wehr Hans. Mu'jam al-Lughah al-Arabiyyah al-Mu' ashirah, ed. J Milton Cowan, o London Macdonald \&Evans Ltd, 1980. 